\title{
Louis Henri de Nicolay between France and Russia
}

\author{
Roger Bartlett \\ University College London \\ roger.bartlett@ucl.ac.uk
}

Rodolphe Baudin E Alexandra Veselova, eds., Louis Henri de Nicolay, un intellectuel strasbourgeois dans la Russie des Lumières [Études alsaciennes \& rhénanes]. Strasbourg: Presses Universitaires de Strasbourg, 2020. 279 pp. ISBN 9782868207548.

In 1806 Deputy Minister of the Russian Navy Pavel Vasil'evich Chichagov complained in a letter to his dear friend Semen Romanovich Vorontsov in London about the fact that Russia employed so many foreigners in the state service: this was a "great evil and dishonor." Chichagov imagined a Russian pantheon of Imperial statesmen, inevitably filled however not with native Russians but with "the mausoleums of Czartorisky, of Winzingerode, of Richelieu, of Rosenkampf, of Campenhausen, of Michelson, of Buxhoevden, etc. etc.” The thought made his heart bleed. ${ }^{1}$ In fact, Chichagov challenged the emperor in person about the policy; Alexander I replied without pomp - this was a necessary evil for his Empire, as without it the already insufficient number of competent state servitors would become smaller still. ${ }^{2}$ Chichagov might have included Louis Henri de Nicolay in his pantheon. Nicolay spent most of a lifetime (1769-1820) in Russia, first in the service of the Grand Duke, and later Emperor, Paul and his spouse Maria Fedorovna which led him to high state rank and then to the Presidency of the Academy of Sciences. In 1803, the new Emperor Alexander reluctantly agreed to his retirement, to his favorite estate near Vyborg. In 1806, Nicolay published the poetic work by which he would become known to a wide international audience, The Estate of Mon Repos in Finland, 1804: together with a Ground Plan. ${ }^{3}$

Nicolay (1737-1820), a German-language writer and poet, was also, like Chichagov, a friend and correspondent of the expatriate S. R. Vorontsov. A native of Strasbourg, where he was born, grew up and attended university, he found his way to St. Petersburg via Paris and Vienna and a three-year Grand Tour with a young Razumovskii, and gained employment on the basis of acquaintance and recommendation from Russian aristocrats and fellow servitors. This was a common trajectory for successful foreign servitors in Russia - Rodolphe Baudin here describes his passage from Strasbourg to the Russian capital as "exemplary" (p. 39) - and one facilitated by the standing in the world of Strasbourg city and university, which sent more people to Russia than any other French center except Paris. The Introduction and the First Part of the book under review are devoted to this wider background, offering a wide-ranging discussion of "the

\footnotetext{
${ }^{1}$ P. V. Chichagov to S. R. Vorontsov (February 14, 1806) in Arkhiv Kniazia Vorontsova. 40 vols. (Moscow: Tip. A. I. Mamontova et al., 1870-97), 19: 154-55.

2 "Zapiski P. V. Chichagova" (March 9, 1806) in Russkaia Starina, 50-51 (May 1886), 239-40.

${ }^{3}$ L. H. Nicolay, Das Landgut Monrepos in Finnland 1804: nebst einem Grundrisse (St. Petersburg: Drechsler, 1806). Several later editions; reprint of the 1840 edition, ed. Martin Sperlich, Berlin 1995 (Mitteilungen der Pückler-Gesellschaft, N. F. 10).
} 
mobility of persons and the circulation of knowledge" (p. 15) in Enlightenment Europe and between France and Russia, followed by two chapters on the "Russian networks" of the university's luminaries Jean Hermann, professor of natural history, and the historian Christophe Guillaume Koch.

The question of intellectual and scholarly networks in Europe has been much discussed by Heinz Ischreyt in his investigations of the "European communications system" of the period. In his text edition of the correspondence between Louis Henri de Nicolay and his Berlin namesake, Friedrich Nikolai, Ischreyt evoked a European cultural landscape stretching from England and France to Russia, from the Italian Habsburg provinces to Scandinavia, and connected by a civilizational unity also embracing the small states of Germany. It was populated by a relatively select group of cultured intellectuals confident in their own world view, who sought to exchange ideas, experiences, and objects with like-minded others in a receptive, tolerant, and humane discourse. ${ }^{4}$ Strasbourg and its university, lying bilingually in Alsatian border territory, was a significant hub for such exchanges. Baudin's sophisticated discussion of the modalities of Strasbourgian emigration to Russia maps on to this concept, covering wider factors such as the over-supply of graduates produced by the university, its favorable location for international travellers and aristocratic Grand Tourists, and other pull and push factors, which brought Russian visitors and students to Strasbourg and saw some eighty Strasbourg families established in Russia in the eighteenth century.

The two chapters on Hermann and Koch provide individual studies to flesh out the discussion of correspondence and migration. Both had extensive circles of correspondence, among whose dozen or so Russian correspondents the most regular were Peter Simon Pallas and the mining expert and minerologist Benedikt Franz Hermann. Dorothée Rusque in her study of Jean Hermann tells us (p. 55) that his "epistolary network" was of "medium extent" for the time, with some 210 correspondents and nearly 500 known letters. However, his contacts with Russia arose primarily through Russian subjects attending his private lectures on natural history $(20 \%$ of his auditors were Russian subjects or Poles) and from interest in, and visits to his cabinet of objects from the natural world - here the percentage of Russians was smaller, but the proportion of high Russian aristocrats much larger. The cabinet, Hermann's "encyclopaedic project" (p. 67), like the library attached to it, covered the three realms of nature, mainly in Europe, but potentially world-wide. Specimens and books became the currency of "a true exchange economy" (p. 68) primarily with members of the Russian Academy of Sciences, and Hermann used his auditors and well-placed visitors as channels for further contacts and acquisitions. This led to rich Russian connections, which faded only with the coming of the revolutionary wars in the 1790 .

Rodolphe Baudin and Wladimir Berelowitch draw on a previous monograph to portray the work of Christophe-Guillaume Koch, ${ }^{5}$ an historian notable for his great

\footnotetext{
${ }^{4}$ Die beiden Nicolai. Briefwechsel zwischen Ludwig Heinrich Nicolay in St Petersburg und Friedrich Nicolai in Berlin (1776-1811), hrsg. und kommentiert von Heinz Ischreyt (Luneburg: Vg. Nordostdeutsches Kulturwerk, 1989), 7-8. Cf. Buch- und Verlagswesen im 18. und 19. Jahrhundert: Beiträge zur Geschichte der Kommunikation in Mittel- und Osteuropa, hrsg. H. G. Göpfert u.a., red. Heinz Ischreyt (Berlin: Camen, 1977).

${ }^{5}$ Christophe-Guillaume Koch, Histoire de la Russie, avec sa partie politique, suivie de la Constitution de l'Empire de la Russie, édition établie, annotée et présentée par Rodolphe Baudin et Wladimir Berelowitch [Études alsaciennes et rhénanes] (Strasbourg: Presses Universitaires de Strasbourg, 2018).
} 
success in teaching the exclusive courses of Strasbourg University's Ecole Diplomatique from the 1770s. This has sometimes been overplayed: Baudin dismisses as exaggerated a claim that a majority of Russian delegates to the Congress of Vienna had been students of Koch and his predecessor. The second part of the chapter focuses on Koch's close relations with a Golitsyn family and on the History of Russia, which he prepared for one of its scions, his student Aleksei Andreevitch Golitsyn. The analysis of Koch's sources shows him well-informed and drawing on a wide range of recent publications, principally but not only by German authors, also making unacknowledged use of Schlözer and French historians of Russia. While critical of things Russian of which he disapproved, Koch showed himself generally well-disposed to the Empire, something (note the authors) that was a widespread sentiment in the Europe of his time.

This First Part of the book, occupying nearly 100 pages, thus sets the scene for Nicolay's departure and arrival in St Petersburg; Nicolay himself appears only rather fleetingly. It is at the same time a celebration of Strasbourg and its university in the eighteenth century as a center for international communication and European engagement with Russia. It might have been productive to compare it in these respects with other universities, whether French or German, in the latter case most obviously Göttingen, and its outstanding scholar August von Schlözer, ${ }^{6}$ which are mentioned briefly here but not given any extended consideration. Strasbourg's undoubted success in cultivating Russian connections was by no means unique in the European communications network.

The Second Part of our book is devoted to Nicolay's state service in Russia, first as tutor to Grand Duke Paul and personal secretary to Paul and Maria Fedorovna (chapter 3, by Moritz Ahrens), then as President of the Academy of Sciences (chapter 4, Natalia Prokhorenko). Nicolay's appointment in 1769 followed directly from d'Alembert's refusal of Catherine II's invitation to become tutor to her son - Nicolay had met Diderot and d'Alembert during a stay in Paris, and the latter had himself drawn Nicolay's attention to the situation. Since Paul's principal tutor, Count Panin, dealt with matters pertaining to state affairs, Nicolay's appointed domain was culture and literature. Nicolay found that his new role gave him much leisure, and he used the free time to compose three educative texts for his pupil. An allegorical tale entitled "Beauty" explored the different forms of virtue and portrayed the connection of virtuous behavior with beauty. The other two were translations, one from the Scottish historian William Robertson, whose work had greatly interested Nicolay during his two-year stay in England with Razumovskii, and the other a translation of the Agricola of Tacitus, an author much valued by Robertson, as also by Nicolay's grand Parisian contacts Diderot and d'Alembert. Thus, while Koch in Strasbourg had drawn on French and German sources for the History he composed for Golitsyn, Nicolay's inspiration was a British writer who insisted on the importance of history and historical texts in the education of princes. A further Robertsonian text, Address to His Imperial Highness Grand Duke Paul on the Occasion of his Majority, was composed in 1772 and published in a variety of formats; a version re-worked as a verse "epistle" appeared among Nicolay's Divers Poems

\footnotetext{
${ }^{6}$ See recently Martin Peters, Altes Reich und Europa: der Historiker, Statistiker und Publizist August Ludwig (v.) Schlözer (1735-1809) (Münster: LIT Verlag, 2003).
} 
of $1778 .{ }^{7}$ Ahrens gives a detailed history of the somewhat convoluted publication history of these works, which were a prelude to further literary endeavors. He concludes by juxtaposing Nicolay's impressive achievements as state servitor with the great significance of his literary and poetic writings, which Nicolay continued in Russia. Ahrens remarks that histories of German literature have yet to render due justice to Nicolay's poetic oeuvre: but he leaves this task to "future researchers" (p. 124) - this whole book tells us very little about Nicolay's overall poetic practices or achievement.

Natalia Prokhorenko begins her discussion of Nicolay's term as President of the Academy of Sciences with consideration of his survival strategies over thirty years at the Young Court of the mercurial and temperamental Grand Duke and his two wives, especially the amiable second wife Maria Fedorovna. Nicolay, we learn, gave proof of a supple and agreeable character and a genuine devotion to his service to the grand-ducal couple, which allowed him to escape the disgrace so frequently inflicted on members of Paul's court, and to gain the respect and liking of both the couple. Consequently, when Paul came to the Imperial throne and had a free hand with honors and promotions, Nicolay's official status underwent a meteoric rise. On the new emperor's accession in 1796, he was made a Secretary of State and received an estate of 1500 peasant souls. In 1797, Paul confirmed the barony of the Holy Roman Empire previously conferred on Nicolay by the Emperor Joseph II, awarded him the Order of St. Anne, first class, and promoted him Actual State Counsellor. The following year, he was installed as President of the Academy of Sciences; in 1800 , he became a Privy Counsellor.

The presidency was to some extent a ceremonial post, as the Academy also had a director. The previous president, Count Kirill Razumovskii, had delegated management almost entirely to successive directors, first the very successful Ekaterina Romanovna Dashkova (1783-94), then Pavel Petrovich Bakunin (1794-98), who exceeded his powers, fell out with the academicians and resigned, leaving the Academy in some disarray. Nicolay had at once to address urgent difficulties over the status of the Academy's gymnasium and the unwelcome obligation created for it to provide censors of foreign books; he also had to navigate increasing interference by the tsar himself, whose interventions effectively reduced the role of the president to that of the director. Most importantly, however, Nicolay as President composed a draft of a new governing statute for the Academy, which created a vice-president drawn from among the academicians to oversee the daily administration of the Academy and the gymnasium, and also assigned an important role and greater freedoms to the academicians themselves in the life and work of the institution. This draft was evidently drawn upon when the new Emperor Alexander asked Nicolay in 1801 to produce a new statute, which passed into law in 1803 and gave new privileges and better financial support to the Academy's members. By this time however, Nicolay, now aged 66, wished to retire: with the support of Maria Fedorovna, he succeeded in overcoming the reluctance of the emperor, was released from service, and withdrew in 1803 to Monrepos, to which Part Three of the volume is devoted.

Chapter Five (Ioulia Mochnik and Mikhail Efimov) is entitled "Louis Henri de Nicolay décorateur de son domaine: à propos de l'une des statues du parc de Monrepos." Emphasizing the essentially European (as opposed to Russian) basis of Nicolay's

\footnotetext{
${ }^{7}$ Edmund Heier, "William Robertson and Ludwig Heinrich von Nicolay, His German Translator, at the Court of Catherine II," Scottish Historical Review, 41, No. 132, Part 2 (1962), 135-140. Heier failed to appreciate that the Address and the Epistle were essentially the same work.
} 
sensibilities and viewing Monrepos as "the work which Nicolay himself regarded as the most perfected" (p. 148), the authors suggest that Monrepos was a laboratory in which Nicolay sought to achieve a synthesis of antique mythology, the European neoclassical aesthetic, and his own rather free interpretation of local Finnish culture. They focus on one of the statues in the Monrepos park, The Spring of Narcissus, as a perfect illustration of "these cultural dialogues" (p. 149), both part of a significant group of statuary and a central feature of his 1806 publication about the estate. The chapter is a brilliant but narrowly focussed investigative account of the building of the granite spring basin over which Narcissus presided, and of the statuary itself, which is traced back to statues acquired in the eighteenth century for the Summer Garden in St. Petersburg. The statue of Narcissus at Monrepos was shattered by an artillery shell during the Finnish-Soviet war, and the remains finally removed in the 1950s. Besides being a contribution to the history of Monrepos, this narrative is offered both as an illumination of the artistic tastes and cultural connections of Nicolay, and as a chapter in the reception of Italian sculpture in the Russian capital.

In Chapter Six, "Louis Henri de Nicolay, Monrepos et la poésie des jardins,” Anna Ananieva places Monrepos and Nicolay's poem in the context of garden art and poetry. Ananieva is the author of an outstanding history of early modern Russian gardens and their cultural and literary reflection, also of a previous article on Monrepos and Nicolay's poem; ${ }^{8}$ her focus here is on the latter. Das Landgut Monrepos, a product of the double tradition of landscape garden art and of garden literature, opens with references to the classic home of landscape gardens, Britain, and to Switzerland, site of the poetic idylls of Salomon Gessner; the poem's opening also presents its dominant theme of tranquillity, evoked particularly through reference to antiquity and the iconic name of Tibur/Tivoli. The 1806 edition, published after years of protracted remodelling and embellishment of the estate, was the first of four over the next decade; "the cultural ambition of Nicolay's project appears in the visible connection which ties the improvement of the park to the traditions of garden poetry" (p. 176). Ananieva emphasizes the immense popularity of garden poetry at the turn of the eighteenth century and the interpenetration of gardens and texts. Nicolay wanted his poetry to awaken feeling in the reader in the same way as his park-garden did in the viewer, to reinforce the impression made by Nature and to elucidate it where it was unclear or weak. Here he stood in the tradition of the celebrated French poetic work on landscape gardens of Jacques Delille (1782, later editions 1800 , 1801), which aroused great interest and several translations in Russia and two of whose editions stood in the library of Monrepos. Nicolay's experience of garden parks and their poetry went back at least to his European journey with Paul and Maria Fedorovna in their guise of Count and Countess of the North in 1782 , when the Imperial couple had been entertained at several park estates and had been present when the newly published work of Delille was presented at Versailles during their visit. In a letter to Friedrich Nikolai, Louis Henri reflected that if he left no splendid verses, he would at least have given the world a beautiful garden, which was already more famous than was he himself; and that

\footnotetext{
${ }^{8}$ Anna Ananieva, Russisch Grün. Eine Kulturpoetik des Gartens im Russland des langen 18. Jahrhunderts (Bielefeld: Transcript-Vg., 2010); eadem, “'Zwar nicht in Albion, nicht an dem See der Genfer...': Poeticheskoe opisanie parka Monrepos. L. G. Nikolai v kontekste evropeiskogo diskursa o sadakh," in Monrepo: Al'manakh (Vyborg, 2010).
} 
landscape creation (das Bauen) was also more pleasant than composing poetry (das Schreiben) (p. 191).

This is an impressively erudite discussion of Nicolay's master work, describing its context in detail and giving a good indication of Nicolay's own attitude to it. But one wonders whether Nicolay himself was altered by the Monrepos experience or sought anything else from it besides his publicly proclaimed goals of sentiment and tranquillity: Goethe's fictional Wahlverwandschaften (Elective Affinities, 1809) comes to mind, where the remodelled landscape garden reflects the psychological development of the characters and becomes almost a participant in their story, or Andreas Schönle's recent discussion of the deliberate self-fashioning of I. I. Bariatinskii, in which estate design and landscape architecture played a central but instrumentalized role. ${ }^{9}$

Part Four of this work explores "the posterity and representations of Louis Henri de Nicolay." Chapter 7 (Alexandra Veselova) analyzes the posthumous picture of Nicolay which emerges from Russian biographical accounts of the second half of the nineteenth century, which in the words of one writer tend to show him as "a dry German Academician," reflecting his position as head of the Academy of Sciences. The choice of time-period is determined by the fact that the later nineteenth century saw renewed attempts to reform and reshape the Academy. This stimulated retrospective views of its development and also brought to the fore the perennial friction within the organization between Russian and foreign members. This tension was the starting point of the only serious biographical study of Nicolay in the period, an article by the writer and publicist E. M. Garshin, ${ }^{10}$ who praised Nicolay as a rare type of German who did not obstruct the progress of Russian science, unlike most other (haughty and destructive) German academicians. Other accounts gave more-or-less favorable pictures, the negative portrayal that called him a "dry German Academician" provoking an indignant rebuttal from Nicolay's grandson. Overall, however, Veselova concludes, Nicolay's reputation in the later nineteenth century was excellent, above all because of his identification with the admired Academy statute of 1803: while his life and work were neglected, his role in the Academy assured that he would be remembered by posterity.

Chapter 8 (Mikhail Efimov) examines the portrayal of Nicolay in a twentieth-century work of fiction, Iurii Tynianov's Kiukhlia (1925), a novel about the Decembrist conspirator Wilhelm Küchelbecker. Nicolay had indeed known the Küchelbecker family, since Karl Küchelbecker, the father of Tynianov's (anti-)hero, managed Grand Duke Paul's palace of Pavlovsk when Nicolay had charge of the Grand Duke's finances. Chronology, however, makes it extremely unlikely that Nicolay could have participated in the Küchelbecker family consultation in which Tynianov places him, unkindly caricatured. The humiliating portrait of a ridiculous elderly German given by Tynianov contributed to the social build-up of the novel and the alleged psychology of its central personage Wilhelm. In 1963, Tynianov's book was made into a film - the only time, Efimov suggests, that the Soviet public at large ever got to hear of Nicolay. This brief article is well researched, though not of great interest, but raises wider questions of literary portrayal - has Nicolay or Monrepos appeared in other fiction? It has not been

\footnotetext{
${ }^{9}$ Andreas Schönle, "Self-Fashioning, Estate Design, and Agricultural Improvement: I. I. Bariatinskii's Enlightened Reforms of Country Living," in The Europeanized Elite in Russia 1762-1825: Public Role and Subjective Self, eds. A. Schönle, A. Zorin, A. Evstratov (DeKalb: Northern Illinois University Press, 2016), 136-54.

${ }^{10}$ E. M. Garshin, “Akademicheskii nemets proshlogo stoletiia," Istoricheskii Vestnik VIII (1882), 127-37.
} 
possible to check whether Countess Euphemia Ballestrem-Adlersfeld's crime novel Schloss Monrepos (published in Dresden in 1911) is set in Karelia or elsewhere; but further investigation might prove fruitful.

The text of our book is rounded off by Rodolphe Baudin's "Conclusion: The Multiple Identity (L'identité plurielle) of an Alsatian of the Enlightenment." His brisk and lucid summary of the themes addressed by the contributors rehearses Nicolay's successful Russian career, emphasizes his membership in the Republic of Letters, and also brings in Nicolay's late translations of French dramas and reference to his extensive correspondence, which is referred to repeatedly in the different chapters but never quantified or characterized. Baudin's main focus, however, is on Nicolay's status as an agent and participant in the international circulation of culture, ideas, and people, especially between France and Russia. But he sees Nicolay not as a deliberate international broker of cultural exchange, but rather as an Alsatian displaced in Russia, who never learned Russian properly, relying on his European French and German throughout his Russian career, and - rather than returning to his country of origin as did many cultural brokers - created for himself a retreat in an "intermediary space" on the northern edge of Russia, where his pre-romantic (Ossianic) and neo-Classical sensibilities could also take cognizance of local Finnish culture. Monrepos, an "objetfrontière" (p. 221), was in some sense a recreated Alsace, a dream realized in a space of displacement.

The book is completed by appendices presenting five unpublished letters of Nicolay, which give new detailed information about Nicolay's removal to, and arrival in Russia, and a useful chronology of his life and works. These are followed by succinct chapter summaries in French and Russian, a list of the contributors, illustration credits, and a table of contents; the very full bibliography is contained solely in the footnotes, and there is no index. The book is extremely well produced, attractively designed, and illustrated; Russian contributions have been felicitously translated by Rodolphe Baudin. Faults or errors seem to be very few - curiously, the town of Radzivilov is (mis)spelled in three different ways on the two pages 134 and 135; and a significant mistranslation gives "akademicheskii nemets" as "un Académicien allemand" (p. 201), important because of its cultural connotations: in the late nineteenth-century context a German who happens to be an academician is not the same as an academician who happens to be German.

This volume was based on a Franco-Russian conference held at the University of Strasbourg, a gestation that shows in the nature of its different contributions. It gives, above all, a literary and culturological account of Nicolay and his Russian dimensions. It has no pretensions to offer extensive biographical coverage: readers are referred to standard biographical dictionaries. And nowhere in this volume do we learn any serious detail of the social or economic history of Nicolay's service or of Monrepos: Nicolay's wife barely exists, and as family man at home or as Karelian land- and estate-owner, he is absent from (for example) Anna Ananieva's discussion, as well as from Rodolphe Baudin's Conclusion dealing with the protagonist's "multiple identity." Nevertheless, the editors have succeeded in giving coherence and unity to this attractive and engaging volume, which is an apt celebration of the University of Strasbourg and a fine tribute to a secondary, but significant figure of the late European Enlightenment. 